\title{
Mari Traditional Medicine Origins and Prospects
}

\begin{abstract}
Annotation
The author focuses on the need to study the actual problems in the ethnic cultures of the Russian Federation. The topic of the article is closely associated with the development of traditional medicine of the Mari living in the territory of the Republic of Mari El as well as in many regions and republics of the Volga Region and the Ural.

Mari traditional medicine is not only a phenomenon of local culture, but also a national religious system called Chimari Yulla. This kind of pagan religious forms belongs to the most ancient religions on the territory of Russia. Taking into account the fact that Mari medicine and religion have the oldest origins and traditions, which practically did not change at present, the research carried out by the author will be in demand and interesting in domestic and foreign scientific community.
\end{abstract}

Keywords: Ethnic culture; Traditional medicine; Mari; Mari El republic; Volga region; Ural; Chimari Yule; Religious system; Traditions; Ethnography; Healing
Mini Review

Volume 8 Issue 1 - 2017

Golovin Vitaly Fedorovich*

Russian association of alternative medicine, Russia

*Corresponding author: Golovin Vitaly Fedorovich, Russian association of alternative medicine, founder and president of "Academy of Harmony and Health" Kazan, Russia, Email: 433-183@mail.ru

Received: June 13, 2017 | Published: July 25, 2017

\section{Mini Review}

The millennial medical traditions of different nations of the world contain aspects of knowledge that surpass the efforts of modern medical science. When the logic of modern societal development compels official medicine to turn to this knowledge, its representatives must investigate the principles by which such knowledge evolved.

Additionally, the question of responsibility in modern medicine has emerged as a prominent discussion, as has the objective of its study: human health. It is therefore necessary to answer the question of why, today--in the era of globalization and the functioning of international medical structures--it is sometimes much more difficult to preserve and strengthen human health than in previous centuries, when a human was very closely connected with nature, tried not to violate its order and endeavored to maintain harmony with the environment.

Our country has long pursued wisdom and achievement in classical medicine. Anything that did not fit into this dogma was considered to be charlatanism. (This is a debatable question, as we can only agree that there have been many charlatans in the field of classical medicine, especially nowadays.) Moreover, the mention of folk (traditional) medicine was not allowed in the formation of a scientific worldview or the professional knowledge of a practicing physician.

It was only over the course of time that the situation began to change, and today orthodox physicians are increasingly forced to state that the use of various grandmothers' recipes gives results that those in the world of classical medicine can only dream about. First, almost underground, and then emerging with increasing energy, such means began to study and explain them scientifically. It has also been noted that the combination of such techniques with classical medicine is striking in its effectiveness.

Today, people of various ethnic cultures are discovering miraculously surviving old books with recommendations and advice from so-called witch doctors of previous centuries. We respectfully began to treat old recipes, the use and popularization of which even became something of a trend at the beginning of the twenty-first century. Thus, the methods used by our ancestors are having a renaissance in Russia and the world, as well as a certain status.

A special place in the vast space of traditional medicine was occupied by the knowledge of one of the old ethnoses living within the territory of what is now the Russian Federation, known as the Mari (the obsolete Russian name is Cheremises) [14, pp. 519-524]. The geographic range of this ethnos is predominantly that of the Mari El Republic, but it also includes various regions and republics of the Volga Region and the Ural [22, C. 2-6].

The history and culture of Mari is the subject of research by many researchers. Among them we will name [1-22] It should be noted that out of the total number of existing studies (not all authors are represented here), only the works of V.N. Petrov are devoted directly to the study of the theme of the Mari traditional medicine. All other works help to explore this issue in the historical, religious, philosophical and socio-cultural aspects.

Consequently, the question does not lose its relevance, when conceived the basic idea of traditional medicine of ancient ethnic groups, of which the Mari are prominently representative? It is known that the first signs of primitive medical care were revealed even in the period of the primitive communal system, in the history of which the primitive human herd can be distinguished (the Lower Paleolithic), and in the era of the primary-tribal system (Upper Paleolithic and Neolithic). Remains of the pollen of medicinal plants have been found in Neanderthal burial sites. 
At the same time there were ideas about hostile magical (natural and supernatural) forces and mysterious creatures that caused illnesses, particularly when people were not influenced by them, did not want to blandish them and so forth. Therefore, magical, religious views on nature developed (including among the Marialong with primitive materialistic ideas about the nature of diseases [19, p. 62]. However, these and other views shaped the system of the world view of the Mari, which was not limited to empirical methods and treatment skills but also attempted to understand the causes of the development of existing diseases.

It should be stated that the Mari had the use of medicinal plants, because the predecessors of this genus considered nature to be the best healer, and medicinal plants could therefore provide reliable, effective treatments for various diseases. This empirically formed thesis was based on the ancient kinship underlying the closeness of people and plants, which can now be proved by analyzing the list of constituent chemical elements that are part of animal and plant tissues.

The emergence of translated handwritten editions-herbologies--made clear to contemporaries the means to accurately combine various herbs. This was a benefit of accrued experience in the use of herbal treatments. The Mari, in their treatment books, described herbs and the compositions of recipes as well as ways of treating "external" diseases of the skin and oral cavity. Significant importance was attached to bone-healing, in which some ancient methods of comparing bone fragments and the forcible reduction of deformities and vertebral discs have retained their significance to the present day.

The methods of Mari traditional medicine include the treatment and prevention of physiological disorders in the body, particularly certain diseases, with the help of herbs, minerals, animal products, apiotherapy (treatment with bees) and treatment with ants.

The traditional medicine of the Mari healer was a phenomenon of spiritual culture at all stages of the historical development of the ethnos. His high intellect, consecrated by thousand-year-old wisdom, was expressed not only as love for the land and work, but he also reigned in rituals, songs, conspiracies, ritual festivals, healing magic with words, things, numbers, charms and curative plants. His esteemed position was reflected in everyday life and folklore as well as in the works of ethnographers and historians.

Significant importance was given to the process of treatment and prevention of immune disorders and somatic disorders, popularly called "evil eye." In fact, such disorders were treated as hidden psycho-emotional blocks in the human subconscious that would form an "energy recession or, in other words, a lack of energy or a sense of impossibility or great difficulty in the realization of one's aspirations, even in the absence of obvious external factors. In this case, the Mari used the method of suggestion associated with the use of stable expressions in the form of short formulas or prayers addressed to the forces of nature.

Methods that can be conditionally called Mari meditations, or so-called meditation of relief, were widely used. Additionally, Mari witch doctors (yuzo) would use a system of acupuncture and reflexotherapy. Perhaps not entirely unique, but at least noteworthy, is the Mari massage. It is distinguished from other forms of massage by the fact that it is performed without the use of force. Therefore, it is called lyzhge viy (quiet power). The massage allows one to quickly remove tension in any muscle group both in striated and smooth muscles, thus allowing the rapid alleviation of swelling and soreness while normalizing the microcirculation of body fluids. This can be confirmed through methods involving hardware and laboratory objective diagnosis.

A significant place in the treatment was previously given to ritual forms of traditional doctoring. Currently, less attention is paid to this, although from the standpoint of modern medicine and psychology they are somewhat effective methods of ethnocultural psychological correction and can be used in group therapy as a figurative meditative therapy for treatment and prevention.

The greatest value of Mari traditional medicine is that it teaches the patient to employ a careful attitude to nature in general and to his health in particular. It reasonably asserts that the physical processes of pathology are caused primarily by the fact that a human moves away from nature or loses connection with nature. In other words, the individual has more time in his imagination, namely in his plans, dreams and nervous state of mind. In this state, the individual does not see reality; he does not truly recognize the sky, the sun and the clouds. In the literal sense, the individual may of course see these things but will not pay attention to them. Only when the consciousness is too overloaded does the subconscious activate its defense mechanism and, first, initiates the process of pain as a sensation. This process becomes chronic and triggers other processes in the body if the individual does not heed reality. This problem originates from the fact that the individual identifies too strongly with his thoughts and therefore loses touch with reality.

Many cultures have their own prevention measures designed to prevent this phenomenon. In Mari medicine, the witch doctor will advise the patient to communicate more with nature. He will suggest different breathing exercises and apply the aromas of herbs and trees, even in urban conditions, particularly when the individual is heavily burdened with emotional problems.

A witch doctor will recommend that the patient repeatedly, throughout the day, shift his or her attention to the sensation of the surrounding odor (without evaluation, good or bad), using just two to five breaths and sniffs, sniffing at every breath to the smells that are present at the moment. So, gradually the habit of self-relief from mental tension is cultivated. Ultimately, the patient's physical state will be much more balanced.

Considerable attention is also paid to moral/ethical education and physical hardening. Therefore, in the long term it will be necessary to thoroughly study such aspects and, in the process of study, introduce ethnocultural methods of therapy into the general healthcare system as measures for prevention and recovery. All this is critically necessary for future generations so that they can become not only a technology-related civilization but can also have strong, harmonious physical and spiritual health.

The urgency of the methods of Mari traditional medicine in modern times and the possible prospects for its use in the healthcare systems in our country and abroad remain the same. Thus, they continue to draw the attention of scientists and representatives of official, modern medicine. 


\section{References}

1. Baydimirov DA (2009) House-building ceremonialism and semantics of the dwelling of the Mari people. Materials for Internationa research and practical conference "Finno-Ugric as a part of world culture": to the 90th anniversary of Mordovian Republican Joint Local History Museum, Saransk, Russia, p. 34-39.

2. Baydimirov DA (2011) Reflection of traditional religion of the Mar in the everyday life. Latest solutions of modern science: collection of scientific works of post-graduate students. ( $2^{\text {nd }}$ edn), Yoshkar-Ola, Mari State University, Russia, p. 10-13.

3. http://www.science-education.ru/105-7146

4. Bolypov SV (2008) Ancient cult monuments of the Mari El monograph. In: Bolypov SV, Bolshova NA, et al. (Eds.), Yoshkar-Ola, Russia, pp. 163.

5. Vasilev VM (1920) Believes and ceremonies of the Mari. News of the Society of Archeology, History and Ethnography. ( $1^{\text {st }}$ edn), Kazan, Russia, p. 49-70.

6. Vasilev VM (1928) Mari religious sect "Kugu sorta". Yoshkar-Ola, Russia, pp. 127.

7. Vasilev VM (1927) Materials for studying believes and ceremonies of the Mari. Krasnokokshaysk, Russia, pp. 127.

8. Glukhova NN (1994) Expressivity of the Mari pagan grounds. Finnougrovedenie, Russia, p. 38-52.

9. Gorodskoy G (1864) About Cheremises living in the Krasnoufimsky County of the Perm government.Ethnographic collection of the Russian Geographical Society. (6 $6^{\text {th }}$ edn), Russian, p. 23-34.

10. Evseev TE (1927) Customs, believes and superstitions of the Mari / Mari El, Russia, pp. 125-165.

11. Yu A, Kaliev (2001) Religious beliefs. The ethnography of the Mari people: senior classes training manual / Yoshkar-Ola, Mari book publishing house, Russia, pp. 184.
12. Yu A, Kaliev (2003) Mythological mind of the Mari. Phenomenology of traditional worldviews: Monograph / Yoshkar-Ola, Mari State University, Russia, pp. 216.

13. Kuznetsov SK (1905) A trip to the ancient Cheremis shrine known since the time of Olearius / Ethnographical review, Russia, pp. 129157.

14. (2000) The Mari / East Mari/ Mountain Mari / Meadowy Mari / Northwestern Mari // Encyclopedia of the Republic of Mari El. In: Vasyutin MZ, Garanin LA et al. (Eds.), Mari Research Institute of Language, History and Literature, Russia, pp. 519-524.

15. Mochaev VA (2007) Mari Biographical Encyclopedia / Yoshkar-Ola, Mari Biographical Center, Russia, pp. 486.

16. Nikolsky DP (1896) About Cheremises: ethnographic and anthropological sketch // Notes of the Ural Society of Natural Science Lovers / V. XVII, Edition No. 1, Yekaterinburg, Russia, pp. 83-117.

17. Nikolsky NV (1920) History of Mari (Cheremises)/. (1 $1^{\text {st }}$ edn), Kazan, Russia, pp. 180.

18. Nikolsky NV (1916) Program for gathering information about foreigners in the Volga region // News of the Society of Archeology, History and Ethnography. ( $1^{\text {st }}$ edn), Kazan, Russia, pp. 173-186.

19. Novikov SS (2011) Eastern Mari. Philosophy. History. People / V. 4. Yoshkar-Ola, State unitary enterprise "Newspaper "Mari El", Russia, pp. 308.

20. Petrov VN (2003) Mari traditional medicine/Yoshkar-Ola, Russia, pp 116.

21. Petrov VN (1991) Methods of acupuncture of the Mari and their parallels in the traditional medicine of other nations / Interethnic relations of the Mari region people. AEMK. (20 ${ }^{\text {th }}$ edn), Yoshkar-Ola, Russia, pp. 123-153

22. Starikov SV (2009) The Mari (Cheremises) of the middle Volga region and the Cisurals at the turn of XIX-XX centuries / Philokartia, Russia, p. 2-6. 